\title{
TGF- $\beta$ Regulates Hepatocellular Carcinoma Progression by Inducing Treg Cell Polarization
}

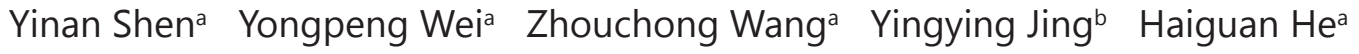 \\ Jianyong Yuan ${ }^{a}$ Rong Lib Qiudong Zhaob ${ }^{b}$ Lixin Weib Tian Yang ${ }^{a}$ Junhua Lu $^{a}$ \\ aThe 5th Department of Hepatic Surgery, Eastern Hepatobiliary Surgery Hospital, the Second \\ Military Medical University, Shanghai, China; 'umor Immunology and Gene Therapy Center, Eastern \\ Hepatobiliary Surgery Hospital, the Second Military Medical University, Shanghai, China
}

\section{Key Words}

HCC $・$ TGF- $\beta \cdot$ Treg cells

\begin{abstract}
Background/Aims: TGF- $\beta$ plays a key role in the progression of various tumors. The main objective of our study was to investigate whether TGF- $\beta$ is able to regulate $N$-nitrosodiethylamine (DEN)-induced hepatocellular carcinoma (HCC) progression in a mouse model by inducing Treg cell polarization. Methods: HCC progression, TGF- $\beta$ and Foxp3 expression levels, serum TGF- $\beta$, IL10 and GP73 levels as well as percentage of Treg cells were analyzed in healthy, HCC and $\mathrm{HCC}+\mathrm{SM}-16$ mouse groups. The effect of TGF- $\beta$ on Treg cell polarization in vitro was measured by flow cytometric analysis. The expression of TGF- $\beta$ and IL10 was identified by IHC in HCC patients and the correlation between TGF- $\beta$ and IL10 was also assessed. Results: TGF- $\beta$ expression is up-regulated in a DEN-induced HCC mouse model. TGF- $\beta$ can promote the differentiation of Foxp $3^{+} \mathrm{CD} 4^{+} \mathrm{T}$ cells (Treg cells) in vitro. However, blocking the TGF- $\beta$ pathway with a specific TGF- $\beta$ receptor inhibitor, SM-16, reduced HCC progression and the percentage of Treg cells in liver tissue. The correlation between TGF- $\beta$ and Treg cells was also confirmed in HCC patients and the expression of both TGF- $\beta$ and IL-10 was shown to be associated with HCC progression. Conclusion: TGF- $\beta$ is necessary for HCC progression, acting by inducing Treg cell polarization.
\end{abstract}

Y. Shen, Y. Wei and Z. Wang contributed equally to this work.

Tian Yang

and Junhua Lu

\section{KARGER 125}

The 5th Department of Hepatic Surgery, Eastern Hepatobiliary Surgery Hospital Second Military Medical University, No. 225 Changhai Road, Yangpu District, Shanghai 200438 (PR China)

Tel. +86-21-81875293, E-Mail lujh0810@126.com, E-Mail yangtian6666@hotmail.com 


\begin{tabular}{|c|c|c|}
\hline Cellular Physiology & Cell Physiol Biochem 2015;35:1623-1632 & \\
\hline and Biochemistry & $\begin{array}{l}\text { DOI: 10.1159/000373976 } \\
\text { Published online: March 18, } 2015\end{array}$ & $\begin{array}{l}\text { O } 2015 \text { S. Karger AG, Basel } \\
\text { www.karger.com/cpb }\end{array}$ \\
\hline
\end{tabular}

\section{Introduction}

Liver cancer is one of the most common causes of cancer mortality worldwide [1]. Among primary liver cancers occurring worldwide, hepatocellular carcinoma (HCC) represents the major histological subtype and accounts for 70 to $85 \%$ of all cases [2]. Although significant progress has been made in recent years, the molecular mechanism which regulates the development and progression of HCC needs to be further explored in order to develop more effective therapies.

The development of cancer is a multi-step and multi-phase process involving the interaction of numerous genes, the influence of the complex environment and the interaction between these factors. Previous studies of HCC focused on gene mutations, such as activation of oncogenes and inactivation of tumor suppressors [3, 4]. However, accumulating evidence has shown that the immune microenvironment plays crucial roles in the development of HCC $[5,6]$, and that tumor infiltrating immune cells, such as regulatory T (Treg) cells, macrophages, neutrophils and Th17 T cells, could be prognostic factors in HCC patients [710].

Treg cells, characterized by the expression of Foxp3, play essential roles in maintaining immune homeostasis and participate in the maintenance of peripheral tolerance and prevention of autoimmunity [11-13]. Studies have shown that Treg cells which have infiltrated tumor sites have the ability to suppress host immune responses and thus could be major obstacles to effective therapy [14-16]. The differentiation of naïve CD4+ $\mathrm{T}$ cells into Treg cells requires distinct effector functions of TGF- $\beta$ [11], which plays essential roles in the regulation of immune responses and immune tolerance $[17,18]$. Wahl and colleagues showed that TGF- $\beta$ could induce the expression of Foxp3 in TCR-challenged CD4 ${ }^{+} C D 25-$ naïve $\mathrm{T}$ cells, which resulted in the conversion of peripheral $\mathrm{CD} 4^{+} \mathrm{CD} 25^{-}$naïve $\mathrm{T}$ cells to $\mathrm{CD} 4^{+} \mathrm{CD} 25^{+}$ Treg cells with potent immunosuppressive potential [19]. Moreover, the role of TGF- $\beta$ in the generation and expansion of Treg cells has also been identified in human peripheral blood [20].

In the present study, we blocked the TGF- $\beta$ signaling pathway using a specific TGF- $\beta$ receptor inhibitor, SM-16 [21], in an N-nitrosodiethylamine (DEN)-induced mouse model of hepatocellular carcinoma [22]. We found that both the tumorigenesis and development of HCC were significantly inhibited when the TGF- $\beta$ signaling pathway was inhibited. Moreover, the frequency of Treg cells in the spleen and liver was obviously reduced in the SM-16 group and the expression level of Foxp3 in liver and lymph nodes was reduced. Administration of TGF- $\beta$ by intraperitoneal injection was able to normalize the frequency of Treg cells and restore the expression level of Foxp3. Moreover, TGF- $\beta$ was positively correlated with IL10 in HCC patients and the expression of both TGF- $\beta$ and IL-10 were shown to be associated with HCC progression. Taken together, these findings revealed that TGF- $\beta$ regulates the development of liver cancer by inducing Treg cell polarization.

\section{Materials and Methods}

\section{Animals, induction of HCC by DEN and SM-16 administration}

The use of animals was approved by the Animal Research Committee at Shanghai Second Military Medical University and all animal experiments were carried out following established International Guiding Principles for Animal Research. Mice were maintained on a $12 \mathrm{~h}$ light/12 h dark cycle at $21-24^{\circ} \mathrm{C}$ in the Animal Housing Unit. Five-week-old male mice were randomly assigned to one of three groups. Healthy group: animals were injected intraperitoneally with normal saline once per week. DEN group: mice were injected intraperitoneally with DEN (35 mg/kg body weight) (Sigma, St. Louis, MO) once per week. The injection was ignored if the mice lost weight $\geq 15 \%$ compared to the previous week [23]. DEN+SM-16 Group: SM-16 was incorporated into standard chow at a concentration of $0.45 \mathrm{~g} / \mathrm{kg}$ of chow [24, 25]. Mice were switched to chow containing SM-16 as soon as they underwent DEN induction. A nutrient-matched diet without SM-16 was used as the control diet. 


\section{Cellular Physiology Cell Physiol Biochem 2015;35:1623-1632 \begin{tabular}{l|l} 
and Biochemistry Published online: March 18, 2015 & $\begin{array}{l}\text { DO 2015 S. Karger AG, Basel } \\
\text { www.karger.com/cpb }\end{array}$ \\
\hline
\end{tabular} \\ Shen et al.: Role of TGF- $\beta$ in HCC Progress}

Clinical specimens

Fresh cancer tissues were obtained from 12 HCC patients in Eastern Hepatobiliary Surgery Hospital, Second Military Medicine University, snap-frozen in liquid nitrogen immediately and stored at $-80^{\circ} \mathrm{C}$ until total RNA was extracted. The clinical characteristics of all patients were available. All patients had previously provided written informed consent for the use of these clinical materials for research purposes and Institutional Ethics Committee approval was obtained.

\section{Quantitative real-time PCR ( $q R T$-PCR)}

Total mRNA was isolated from HCC tissues using TRIzol reagent (Life Technology Corp, Carlsbad, CA) according to the manufacturer's instructions. cDNA was synthesized using a PrimeScript RT reagent kit (TaKaRa, Dalian, China). The expression levels of TGF- $\beta$, Foxp3 and IL-10 were determined using primers designed with the aid of primer 3.0 online and the primer sequences were as follows: TGF- $\beta$ (mouse): forward 5'-AACTTCTGTCTGGGACCCTG-3', reverse 5'-CCGGGTTGTGTTGGTTGTAG-3'; TGF- $\beta$ (human): forward 5'-CCCTACATTTGGAGCCTGGA-3', reverse 5'-CCGGGTTATGCTGGTTGTAC-3'; Foxp3 (mouse): forward 5'-TCCTTCCCAGAGTTCTTCCAC-3', reverse 5'-CGGATAAGGGTGGCATAGGT-3'; IL-10 (human): forward' 5-GGCGCTGTCATCGATTTCTT-3' reverse 5'-CATTCTTCACCTGCTCCACG-3'. The mRNA expression level of $\beta$-actin was used for normalization and the relative expression levels of TGF- $\beta$, Foxp3 and IL-10 were measured by the $2^{-\Delta \Delta C \mathrm{~T}}$ method.

\section{Western blotting}

Livers from the three groups were lysed in RIPA buffer supplemented with protease inhibitors (100 mM Tris, pH 7.4, $150 \mathrm{mM} \mathrm{NaCl,} 5$ mM EDTA, 1\% Triton X-100, 1\% deoxycholic acid, 0.1\% SDS, 2 $\mathrm{mM}$ phenylmethylsulfonyl fluoride, $1 \mathrm{mM}$ sodium orthovanadate, $2 \mathrm{mM}$ DTT, $2 \mathrm{mM}$ leupeptin, $2 \mathrm{mM}$ pepstatin), and then analyzed using a BCA protein assay kit (Beyotime Institute of Biotechnology, Jiangsu, China). Proteins were electrophoresed in a 10\% SDS-PAGE gel. After transfer to polyvinylidene fluoride membranes (Millipore, Billerica, MA) and blocking with 5\% milk, the membranes were incubated with antiTGF- $\beta$ primary antibody (Cell Signaling, Beverly, MA). The corresponding horseradish peroxidase (HRP)conjugated immunoglobulin $\mathrm{G}$ was incubated at room temperature for $1 \mathrm{~h}$. Signals were detected after chemiluminescence reaction with HRP Substrate (Millipore). GAPDH (Cell Signaling) was used as control.

\section{Flow cytometric analysis}

Spleens and livers were mechanically dissociated and red blood cells were lysed, and then samples were strained through a 70- $\mu$ m nylon mesh to produce a single cell suspension. A total of $1 \times 10^{6}$ cells were stained with mAbs at a concentration of $1 \mu \mathrm{L} / 200 \mu \mathrm{L}$ PBS for 30 minutes on ice. The antibodies used were as follows: IFNr-FITC, IL-4-PE, IL-17-FITC, Foxp3-PE and CD4-PerCP-Cyanine5.5 (BD Biosciences, San Diego, CA). Flow cytometric analysis was performed using a FACS Calibur flow cytometer (BD Biosciences).

\section{Immunohistochemistry}

After deparaffinization and hydration, $5 \mu \mathrm{m}$ thickness tissue sections were quenched of endogenous peroxidase activity with $3 \% \mathrm{H}_{2} \mathrm{O}_{2}$ in methanol for 30 minutes and antigen retrieval was performed in sodium citrate buffer. Then, the tissue sections were blocked with 5\% BSA (Sigma) at room temperature for 60 minutes and incubated with primary antibodies at $4{ }^{\circ} \mathrm{C}$ overnight. Color was developed using DABchromogen kits, following by counterstaining with hematoxylin.

Plasma cytokine measurement

The serum levels of TGF- $\beta$, GP73 and IL-10 were measured by enzyme-linked immunosorbent assay (ELISA) using an ELISA kit (R\&D Systems, Minneapolis, MN) following the manufacturer's protocols.

\section{Statistical analysis}

All data presented as the mean \pm SD are from at least 3 separate experiments. Student's $t$-test was used to determine the statistical significance of differences between groups, and a $P$-value less than 0.05 in all cases was considered significant. 


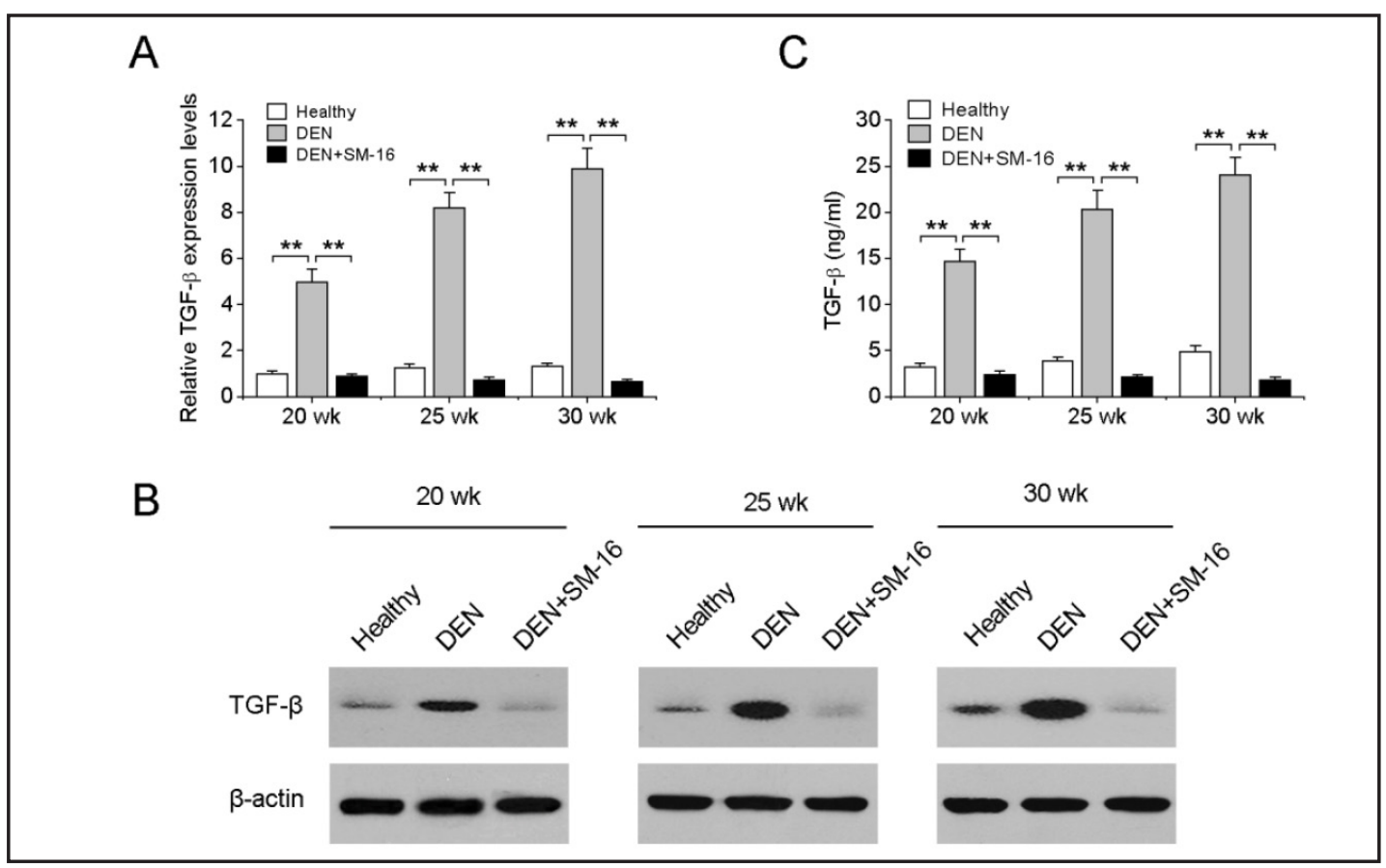

Fig. 1. The effect of SM-16 on TGF- $\beta$ expression in a mouse HCC model. (A) Relative mRNA expression level of TGF- $\beta$ in livers from healthy, DEN and DEN+SM-16 groups at different time points. (B) Western blot analysis of TGF- $\beta$ expression in the three groups at different time points. (C) Serum levels of TGF- $\beta$ measured by ELISA in mice of the three groups at different time points.

\section{Results}

SM-16 inhibited TGF- $\beta$ expression in hepatocellular carcinoma induced by $N$-nitrosodiethylamine (DEN)

The mouse model of HCC was established successfully by DEN treatment. To confirm the inhibitory role of SM-16 on TGF- $\beta$ expression in the DEN-induced HCC model, mice from the three groups (Healthy control, DEN and SM-16+DEN) were sacrificed at different time points after DEN administration. The expression level of TGF- $\beta$ increased significantly along with the development of HCC in the DEN group compared with that in the healthy group, but was obviously reduced in the group that received SM-16 administration (Fig. 1A). TGF- $\beta$ protein expression levels in HCC were also detected by western blotting, and the results showed up-regulation of TGF- $\beta$ expression in the DEN group compared with the healthy group. However, SM-16 reduced the expression of TGF- $\beta$ to a level equal to that of the healthy group (Fig. 1B), which is consistent with the results of mRNA expression (Fig. 1A). Moreover, we analyzed the TGF- $\beta$ content in peripheral blood mononuclear cells (PBMCs). As shown in Fig. 1C, TGF- $\beta$ levels in the PBMCs of the DEN group measured by ELISA were higher than in the healthy group, but were greatly reduced in the SM-16+DEN group compared with the DEN group. Together, these results showed that SM-16 inhibits TGF- $\beta$ expression in a DENinduced model of HCC.

\section{Inhibition of TGF- $\beta$ blocked the development of HCC}

The TGF- $\beta$ pathway plays crucial roles in tumor development due to its essential roles in cell proliferation, differentiation and migration and promotes cancer progression after induction of the epithelial-to-mesenchymal transition (EMT) [26]. We next investigated the influence of TGF- $\beta$ inhibition by SM-16 administration on the development of HCC. As shown in Fig. 2A, the livers were evaluated for their histology by hematoxylin and eosin (HE) staining and the results showed that tissue damage in the DEN-induced HCC group was 
Fig. 2. The effect of TGF- $\beta$ inhibition on HCC development. (A) Representative H\&E staining of livers from the three groups of mice at different time points. Original magnification, 200×. (B) Serum levels of GP73 measured by ELISA in mice of the three groups at different time points.
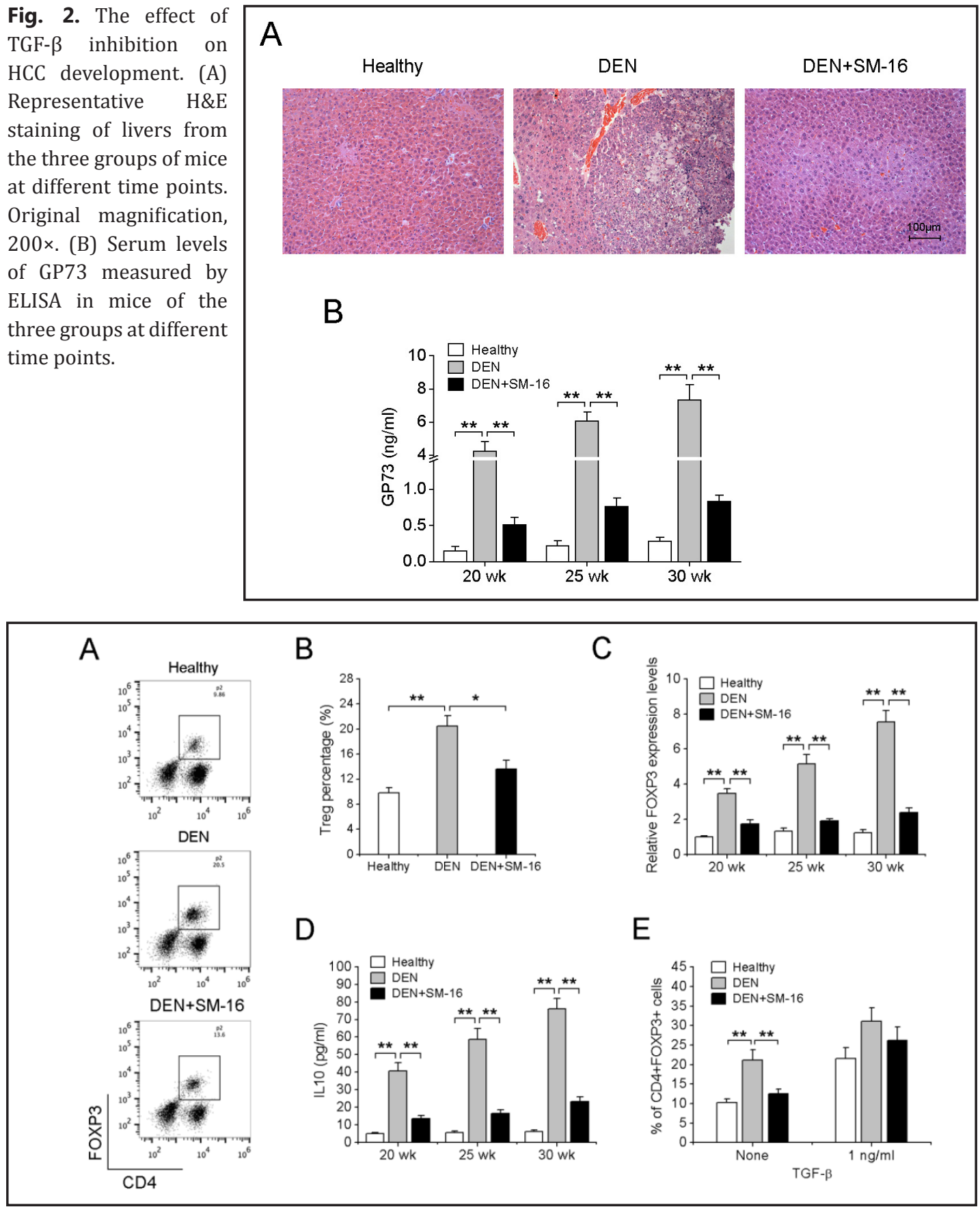

Fig. 3. The effect of TGF- $\beta$ on Treg cell expression and differentiation. (A) Representative flow cytometric analysis of Treg cells from the spleens of the three groups at 25 weeks. (B) Quantitation of the CD4 ${ }^{+}$Foxp3 ${ }^{+}$ Treg cells shown in A. (C) Relative mRNA expression level of Foxp3 in livers from the three groups at different time points. (D) Serum levels of IL10 measured by ELISA in mice of the three groups at different time points. (E) Quantitation of Treg cells from the spleens of 25 week-old mice in the three groups without (None) or with TGF- $\beta(1 \mathrm{ng} / \mathrm{mL})$ stimulation.

increased markedly compared with the healthy group, as evidenced by dense liver tissue and increased neutrophil infiltration. However, tissue damage was reduced to levels equal to that seen in the healthy group after SM-16 administration in the DEN+SM-16 group, indicating that TGF- $\beta$ inhibition plays a protective role against liver tissue damage. 
A

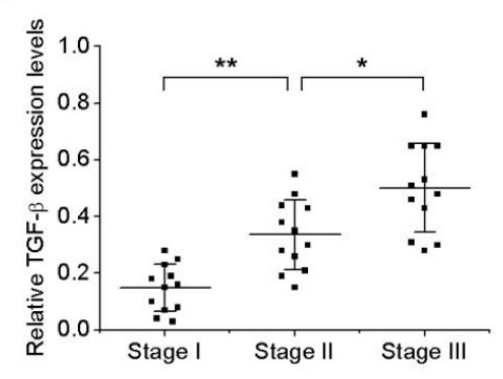

C

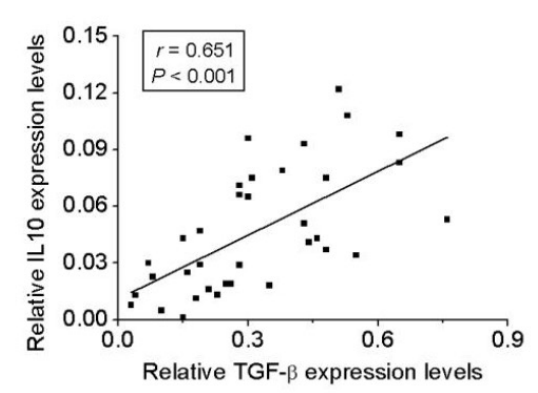

B

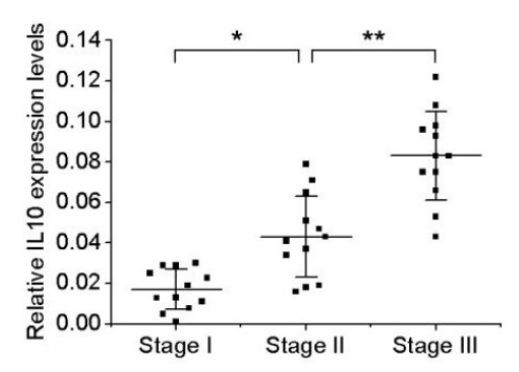

D

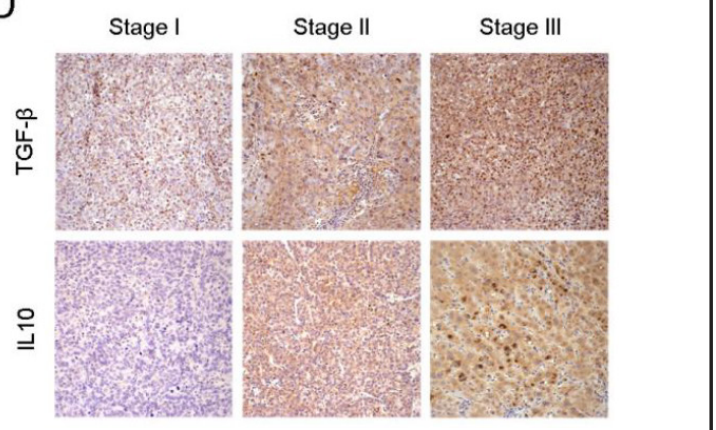

Fig. 4. The relationship between TGF- $\beta$ and IL10 in HCC patients. The relative mRNA expression level of TGF- $\beta$ (A) and IL10 (B) in HCC patients of different stages $(n=12)$. (C) Correlation between TGF- $\beta$ and IL10 expression determined from the HCC patients shown in A. (D) Representative immunohistochemistry of TGF- $\beta$ and IL10 from the HCC patients shown in A. Original magnification, 200×.

Golgi Protein-73 (GP73), a resident Golgi type II transmembrane glycoprotein, is upregulated in HCC, and commonly considered to be an important serum marker of HCC [27]. As shown in Fig. 2B, the GP73 levels in serum showed no great difference in the healthy group at different time points, but increased markedly with the development of HCC in the DEN group. Consequently, GP73 levels in the DEN group were significantly higher than those of the healthy group at the same time points. However, SM-16 administration reduced GP73 levels in the DEN+SM-16 group compared with the DEN group. Together, these results demonstrate that inhibition of the TGF- $\beta$ pathway by SM-16 administration reduced the development of cancer in a DEN-induced HCC mouse model.

Inhibition of TGF- $\beta$ reduced the percentage and expression level of Treg cells, while exogenous TGF- $\beta$ promoted Treg cell differentiation in vitro

The interaction of the immune system and tumor cells plays crucial roles in tumor progression, and the development of cancer is often considered to be the result of immune system dysfunction, rendering the environment suitable for tumor growth [28]. The types of immune cells infiltrating the liver could be a predictive factor for tumor progression and cancer recurrence $[29,30]$. To investigate this, we determined changes in $\mathrm{CD}^{+} \mathrm{T}$ cell polarization during progression of HCC. CD $4^{+} \mathrm{T}$ cells were isolated from the spleens of the three mouse groups using magnetic microbeads and four major subtypes of CD4+ $\mathrm{T}$ cells (Th1, Th2, Th17 and Treg) were detected by FACS. As shown in Fig. 3A and 3B, the percentage of Foxp $3^{+} \mathrm{CD} 4^{+} \mathrm{T}$ cells (Treg cells) was obviously increased in the DEN group compared with the healthy group, but decreased significantly after SM-16 treatment (DEN+SM-16). However, other CD4+ T cells (Th1, Th2 and Th17) showed no significant difference between the DEN group and the healthy group (data not shown). These results indicate that Treg cells, but not other $\mathrm{CD} 4^{+} \mathrm{T}$ cells, are involved in the development of DEN-induced HCC. 


\section{Cellular Physiology Cell Physiol Biochem 2015;35:1623-1632 \begin{tabular}{l|l} 
and Biochemistry Published online: March 18, 2015 & $\begin{array}{l}\text { C 2015 S. Karger AG, Basel } \\
\text { www.karger.com/cpb }\end{array}$ \\
\hline
\end{tabular} \\ Shen et al.: Role of TGF- $\beta$ in HCC Progress}

Next, the expression of Foxp3 (Treg cells) was analyzed at the transcriptional level. Foxp3 expression was obviously increased along with the development of HCC in the DEN group, and was notably higher than that in the healthy group. However, SM-16 administration reduced Foxp3 expression significantly in the DEN+SM-16 group compared with the DEN group (Fig. 3C). Moreover, the results were further confirmed by analyzing serum levels of IL-10, the effector molecule of Treg cells, by ELISA (Fig. 3D). These results demonstrate that Treg cells are involved in the development of DEN-induced HCC and that TGF- $\beta$ inhibition reduces both the percentage and expression level of Foxp3.

The results described above showed that inhibition of the TGF- $\beta$ pathway reduces the activity of Treg cells, and that this effect is enhanced in DEN-induced HCC. We further determined whether a decrease in Treg cells was due to TGF- $\beta$ inhibition by SM-16 and whether TGF- $\beta$ promotes Treg cell differentiation in vitro. Naïve CD $4^{+} \mathrm{T}$ cells isolated from the spleens of mice in the three groups were activated into Treg cells. As shown in Fig. 3E, the percentage of Treg cells was decreased significantly when TGF- $\beta$ was inhibited (DEN+SM-16) compared with that following DEN treatment, indicating that TGF- $\beta$ inhibition reduces Treg cell polarization. To confirm this, exogenous TGF- $\beta$ was administered and the results showed that TGF- $\beta$ increased Treg cell polarization in mice of both the healthy and DEN groups as expected. In addition, the polarization of Treg cells in the DEN+SM-16 group was rescued by TGF- $\beta$ addition at a concentration of $1 \mathrm{ng} / \mathrm{mL}$ (Fig. 3E). Together, these results show that TGF- $\beta$ promotes Treg cell differentiation in vitro.

\section{TGF- $\beta$ correlated positively with IL10 in HCC patients}

Previous studies showed that the numbers of Treg cells significantly increased in HCC patients compared with those in healthy controls [31]. We next investigated the relationship between IL10 and TGF- $\beta$. HCC patient samples of different stages were used to extract total RNA for transcriptional analysis. As shown in Fig. 4A and 4B, TGF- $\beta$ and IL10 expression increased along with HCC progression. Moreover, correlation analysis between TGF- $\beta$ and IL10 expression was performed and the results showed a positive correlation between them in HCC patients (Fig. 4C). The expression of TGF- $\beta$ and IL10 in HCC patient samples of different stages were also investigated by immunohistochemistry (IHC). The results are shown in Fig. 4D and confirmed the positive correlation between TGF- $\beta$ and IL10 expression in HCC patients.

\section{Discussion}

Hepatocellular carcinoma (HCC) is a life-threatening disease worldwide with high incidence and poor prognosis. More than $60 \%$ of patients are troubled with cancer recurrence, during which the therapeutic approaches are limited because of tumor spread in aggressive forms. The exact mechanism involved in regulating the pathogenesis and development of HCC remains poorly understood and an effective therapy for HCC is urgently needed. In the present study, we found that TGF- $\beta$ is up-regulated in a DEN-induced mouse model of HCC, while SM-16 administration has an obvious inhibitory role on TGF- $\beta$, resulting in reduced development of HCC. Treg cells increase during development of HCC, and TGF- $\beta$ is essential for Treg cell polarization, as evidenced by the finding that inhibition of TGF- $\beta$ by SM-16 led to a significant decrease in the percentage of Treg cells in liver tissue. In addition, addition of exogenous TGF- $\beta$ restored Treg cell numbers to normal levels and promoted Treg cell differentiation. Moreover, TGF- $\beta$ and Foxp3 expression are involved in progression of human HCC and correlate positively in HCC patients.

Previous studies have reported that TGF- $\beta$ plays crucial roles in the progression of HCC. Mazzocca and colleagues have shown that blocking of the TGF- $\beta$ pathway in HCC using an inhibitor of TGF- $\beta$ receptor I kinase, LY21009761, decreased neo-angiogenesis and tumor growth of HCC. In addition, LY21009761 blocked the paracrine cross-talk between HCC and endothelial cells [32]. Fransvea and co-workers reported that TGF- $\beta$ enhanced the invasion 
of HCC cells by specifically phosphorylating beta1 integrin, while inhibition of TGF- $\beta$ by a selective inhibitor blocked the invasion of HCC cells [33]. In this study, we found that TGF- $\beta$ promotes the development of DEN-induced HCC and that inhibition of TGF- $\beta$ by SM-16 impairs the progression of HCC, which is consistent with results previously reported.

Apart from its direct role in regulating tumor progression and invasion, TGF- $\beta$ also plays essential roles in the development of immune cells and controls the differentiation of various $\mathrm{CD}^{+} \mathrm{Th}$ subtypes. Under the stimulation of TGF- $\beta, \mathrm{CD} 4^{+}$naïve $\mathrm{T}$ cells differentiate into Treg cells [34], the infiltration of which into liver tissue is often associated with poor prognosis in HCC patients. TGF- $\beta$ promotes tumor immune escape by maintaining natural Treg levels and enhancing induced Treg cell differentiation. In this study, we found that the frequency of Treg cells increased in HCC and that inhibition of TGF- $\beta$ by SM-16 significantly reduced Treg cell frequency. In addition, we discovered the promoting role of TGF- $\beta$ on Treg cell differentiation in vitro.

Treg cells play critical roles in regulating immune responses, such as blocking inflammation and tissue destruction, inhibiting the function and maturation of antigenpresenting cells, suppressing the production of B cell antibodies, and inhibiting the functions of CD4 helper T cells and CD8 cytotoxic T lymphocyte activity. Production of cytokines such as TGF- $\beta$ and IL-10 is necessary when Treg cells play suppressing roles in immune responses. In addition, TGF- $\beta$ can induce the formation of Treg cells from $\mathrm{CD}^{+}$naïve $\mathrm{T}$ cells and is vital in regulating immune suppression in vivo [35]. IL-10, the effector molecule of Treg cells, is another cytokine that plays important roles in regulation of the immune system. Previous studies have shown that IL-10 is associated with viral-related inflammation in the liver [36]. Moreover, circulating IL-10 is highly up-regulated in a proportion of HCC patients, and high levels of IL-10 are related to hepatic injury caused by cirrhotic processes and predict a poor prognosis $[37,38]$. We found that expression of TGF- $\beta$ and IL-10 increased with progression of HCC, and the relation analysis showed a positive correlation between TGF- $\beta$ and IL-10 expression in HCC patients.

In conclusion, our findings suggest that TGF- $\beta$ is up-regulated in HCC and plays crucial roles in HCC progression by inducing Treg cell polarization. Inhibition of TGF- $\beta$ by SM-16 rescues HCC progression and could be a potential therapeutic target for HCC patients.

\section{Acknowledgements}

This study was supported by National Natural Foundation of China (No. 81172020, 81372262 and 81472284), the Shanghai 'Phosphor' Science Foundation of China (No. 12QA1404800), and Shanghai Program for Excellent Talents in Health System (No. XYQ2011033).

\section{References}

1 Jemal A, Bray F, Center MM, Ferlay J, Ward E, Forman D: Global cancer statistics. CA Cancer J Clin 2011;61:69-90.

2 Perz JF, Armstrong GL, Farrington LA, Hutin YJ, Bell BP: The contributions of hepatitis b virus and hepatitis c virus infections to cirrhosis and primary liver cancer worldwide. J Hepatol 2006;45:529-538.

3 Zender L, Villanueva A, Tovar V, Sia D, Chiang DY, Llovet JM: Cancer gene discovery in hepatocellular carcinoma. J Hepatol 2010;52:921-929.

$4 \quad$ Zhang Z: Genomic landscape of liver cancer. Nat Genet 2012;44:1075-1077.

5 Grivennikov SI, Greten FR, Karin M: Immunity, inflammation, and cancer. Cell 2010;140:883-899.

6 Chen DS, Mellman I: Oncology meets immunology: the cancer-immunity cycle. Immunity 2013;39:1-10. 


\section{Cellular Physiology Cell Physiol Biochem 2015;35:1623-1632 and Biochemistry Published online: March 18, 2015 $\quad \begin{aligned} & \text { DOI: 2015 S. Karger AG, Base } \\ & \text { www.karger.com/cpb }\end{aligned}$

7 Zhu XD, Zhang JB, Zhuang PY, Zhu HG, Zhang W, Xiong YQ, Wu WZ, Wang L, Tang ZY, Sun HC: High expression of macrophage colony-stimulating factor in peritumoral liver tissue is associated with poor survival after curative resection of hepatocellular carcinoma. J Clin Oncol 2008;26:2707-2716.

8 Gao Y, Yao A, Zhang W, Lu S, Yu Y, Deng L, Yin A, Xia Y, Sun B, Wang X: Human mesenchymal stem cells overexpressing pigment epithelium-derived factor inhibit hepatocellular carcinoma in nude mice. Oncogene 2010;29:2784-2794.

9 Zhang JP, Yan J, Xu J, Pang XH, Chen MS, Li L, Wu C, Li SP, Zheng L: Increased intratumoral il-17-producing cells correlate with poor survival in hepatocellular carcinoma patients. J Hepatol 2009;50:980-989.

10 Li YW, Qiu SJ, Fan J, Zhou J, Gao Q, Xiao YS, Xu YF: Intratumoral neutrophils: a poor prognostic factor for hepatocellular carcinoma following resection. J Hepatol 2011;54:497-505.

11 Zhou L, Chong MM, Littman DR: Plasticity of cd4+ t cell lineage differentiation. Immunity 2009;30:646655.

12 Vignali DA, Collison LW, Workman CJ: How regulatory t cells work. Nat Rev Immunol 2008;8:523-532.

13 Sakaguchi S, Yamaguchi T, Nomura T, Ono M: Regulatory t cells and immune tolerance. Cell 2008;133:775787.

14 Kiniwa Y, Miyahara Y, Wang HY, Peng W, Peng G, Wheeler TM, Thompson TC, Old LJ, Wang RF: Cd8+ foxp3+ regulatory t cells mediate immunosuppression in prostate cancer. Clin Cancer Res 2007;13:6947-6958.

15 Curiel TJ, Coukos G, Zou L, Alvarez X, Cheng P, Mottram P, Evdemon-Hogan M, Conejo-Garcia JR, Zhang L, Burow M, Zhu Y, Wei S, Kryczek I, Daniel B, Gordon A, Myers L, Lackner A, Disis ML, Knutson KL, Chen L, Zou W: Specific recruitment of regulatory t cells in ovarian carcinoma fosters immune privilege and predicts reduced survival. Nat Med 2004;10:942-949.

16 Wang HY, Lee DA, Peng G, Guo Z, Li Y, Kiniwa Y, Shevach EM, Wang RF: Tumor-specific human cd4+ regulatory t cells and their ligands: implications for immunotherapy. Immunity 2004;20:107-118.

17 Gorelik L, Flavell RA: Transforming growth factor-beta in t-cell biology. Nat Rev Immunol 2002;2:46-53.

18 Chen W, Wahl SM: Tgf-beta: receptors, signaling pathways and autoimmunity. Curr Dir Autoimmun 2002;5:62-91.

19 Chen W, Jin W, Hardegen N, Lei KJ, Li L, Marinos N, McGrady G, Wahl SM: Conversion of peripheral $\mathrm{cd} 4+\mathrm{cd} 25$ - naive $t$ cells to $\mathrm{cd} 4+\mathrm{cd} 25+$ regulatory t cells by tgf-beta induction of transcription factor foxp3. J Exp Med 2003;198:1875-1886.

20 Yamagiwa S, Gray JD, Hashimoto S, Horwitz DA: A role for tgf-beta in the generation and expansion of cd4+cd25+ regulatory t cells from human peripheral blood. J Immunol 2001;166:7282-7289.

21 Fridlender ZG, Sun J, Kim S, Kapoor V, Cheng G, Ling L, Worthen GS, Albelda SM: Polarization of tumorassociated neutrophil phenotype by tgf-beta: "n1" versus "n2" tan. Cancer Cell 2009;16:183-194.

22 Heindryckx F, Mertens K, Charette N, Vandeghinste B, Casteleyn C, Van Steenkiste C, Slaets D, Libbrecht L, Staelens S, Starkel P, Geerts A, Colle I, Van Vlierberghe H: Kinetics of angiogenic changes in a new mouse model for hepatocellular carcinoma. Mol Cancer 2010;9:219.

23 Heindryckx F, Mertens K, Charette N, Vandeghinste B, Casteleyn C, Van Steenkiste C, Slaets D, Libbrecht L, Staelens S, Starkel P, Geerts A, Colle I, Van Vlierberghe H: Kinetics of angiogenic changes in a new mouse model for hepatocellular carcinoma. Mol Cancer 2010;9:219.

24 Kim S, Buchlis G, Fridlender ZG, Sun J, Kapoor V, Cheng G, Haas A, Cheung HK, Zhang X, Corbley M, Kaiser LR, Ling L, Albelda SM: Systemic blockade of transforming growth factor-beta signaling augments the efficacy of immunogene therapy. Cancer Res 2008;68:10247-10256.

25 Fridlender ZG, Sun J, Kim S, Kapoor V, Cheng G, Ling L, Worthen GS, Albelda SM: Polarization of tumorassociated neutrophil phenotype by tgf-beta: "n1" versus "n2" tan. Cancer Cell 2009;16:183-194.

26 Pickup M, Novitskiy S, Moses HL: The roles of tgfbeta in the tumour microenvironment. Nat Rev Cancer 2013;13:788-799.

27 Marrero JA, Romano PR, Nikolaeva O, Steel L, Mehta A, Fimmel CJ, Comunale MA, D'Amelio A, Lok AS, Block TM: Gp73, a resident golgi glycoprotein, is a novel serum marker for hepatocellular carcinoma. J Hepatol 2005;43:1007-1012.

28 Dunn GP, Bruce AT, Ikeda H, Old LJ, Schreiber RD: Cancer immunoediting: from immunosurveillance to tumor escape. Nat Immunol 2002;3:991-998.

29 Li YW, Qiu SJ, Fan J, Zhou J, Gao Q, Xiao YS, Xu YF: Intratumoral neutrophils: a poor prognostic factor for hepatocellular carcinoma following resection. J Hepatol 2011;54:497-505. 


\section{Cellular Physiology Cell Physiol Biochem 2015;35:1623-1632 \begin{tabular}{ll|l} 
and Bioch: 10.1159/000373976 & $\begin{array}{l}\text { O 2015 S. Karger AG, Basel } \\
\text { www.karger.com/cpb }\end{array}$ \\
\cline { 2 - 3 } &
\end{tabular} \\ Shen et al.: Role of TGF- $\beta$ in HCC Progress}

30 Zhang JP, Yan J, Xu J, Pang XH, Chen MS, Li L, Wu C, Li SP, Zheng L: Increased intratumoral il-17-producing cells correlate with poor survival in hepatocellular carcinoma patients. J Hepatol 2009;50:980-989.

31 Wang Y, Deng B, Tang W, Liu T, Shen X: Tgf-beta1 secreted by hepatocellular carcinoma induces the expression of the foxp3 gene and suppresses antitumor immunity in the tumor microenvironment. Dig Dis Sci 2013;58:1644-1652.

32 Mazzocca A, Fransvea E, Lavezzari G, Antonaci S, Giannelli G: Inhibition of transforming growth factor beta receptor i kinase blocks hepatocellular carcinoma growth through neo-angiogenesis regulation. Hepatology 2009;50:1140-1151.

33 Fransvea E, Mazzocca A, Antonaci S, Giannelli G: Targeting transforming growth factor (tgf)-betari inhibits activation of beta1 integrin and blocks vascular invasion in hepatocellular carcinoma. Hepatology 2009;49:839-850.

34 Flavell RA, Sanjabi S, Wrzesinski SH, Licona-Limon P: The polarization of immune cells in the tumour environment by tgfbeta. Nat Rev Immunol 2010;10:554-567.

35 Zhu J, Paul WE: Cd4 t cells: fates, functions, and faults. Blood 2008;112:1557-1569.

36 Wu JF, Wu TC, Chen CH, Ni YH, Chen HL, Hsu HY, Chang MH: Serum levels of interleukin-10 and interleukin-12 predict early, spontaneous hepatitis b virus e antigen seroconversion. Gastroenterology 2010;138:165-172.

37 Hsia CY, Huo TI, Chiang SY, Lu MF, Sun CL, Wu JC, Lee PC, Chi CW, Lui WY, Lee SD: Evaluation of interleukin-6, interleukin-10 and human hepatocyte growth factor as tumor markers for hepatocellular carcinoma. Eur J Surg Oncol 2007;33:208-212.

38 Chan SL, Mo FK, Wong CS, Chan CM, Leung LK, Hui EP, Ma BB, Chan AT, Mok TS, Yeo W: A study of circulating interleukin 10 in prognostication of unresectable hepatocellular carcinoma. Cancer 2012;118:3984-3992. 